\title{
PENINGKATKAN KEMAMPUAN DALAM PENYUSUNAN RKJM BAGI KEPALA SEKOLAH SD GUGUS VII DURMA UPTD JEBRES SURAKARTA TAHUN 2011/2012 MELALUI SUPERVISI MANAJERIAL
}

\author{
Tri Hartanti \\ UPTD Dikpora Kecamatan Laweyan \\ 3hartanti.solo@gmail.com
}

\begin{abstract}
The research is aimed to: 1) describe the managerial supervision to improve the principals'ability in constructing the RKJM; and 2) to improve the principals'ability in constructing the RKJM for the principals at Gugus VII Durma UPTD Dikpora Kecamatan Jebres of Surakarta through the managerial supervision using group method. The research is an Action Research. The research was done at Gugus VII Durma UPTD Dikpora Kecamatan Jebres of Surakarta. The subject of the research were 5 principals. The data collecting method were done using document and observation techniques. The data analysis was done using path model of Kemmis and Taggart.The research concludes that: 1) the managerial supervision to improve the principals' ability in constructing the RKJM was done as follows: (a) the planning was done in refer to the problems identification; (b) the supervisor and the principals agree the supervision schedule; (c) the supervisor provided the supervision materials in the form of office conference; (d) the supervisor asked the principals to correct the RKJM they made at the end of the sessions; and (e) the supervisor provided training in the indicators that are not mastered by the principals; and 2) the managerial supervision group method is effective in improving the principals' ability in constructing the RKJM. It is demonstrated with the principals ability impovement in each cycles.
\end{abstract}

Keywords: group method,managerial supervision,RKJM construction

\begin{abstract}
ABSTRAK
Penelitian ini bertujuan untuk: 1) mendeskripsikan pelaksanaan supervisi manajerial metode kelompok untuk meningkatkan kemampuan kepala sekolah dalam penyusunan RKJM; dan 2) meningkatkan kemampuan kepala sekolah dalam penyusunan RKJM bagi Kepala Sekolah di Gugus VII Durma UPTD Dikpora Kecamatan Jebres Kota Surakarta melalui supervisi manajerial metode kelompok. Jenis penelitian adalah Penelitian Tindakan. Penelitian dilakukan di Gugus VII Durma UPTD Dikpora Kecamatan Jebres Kota Surakarta tahun pelajaran 2011/2012. Subyek penelitian ini adalah kepala sekolah di Gugus VII Durma dengan jumlah 5 orang kepala sekolah.
\end{abstract}


Teknik pengumpulan data dilakukan dengan teknik dokumen dan observasi. Teknik analisis data dilakukan dengan menggunakan model alur dari Kemmis dan Taggart. Hasil penelitian menyimpulkan bahwa: 1) Pelaksanaan supervisi manajerial metode kelompok untuk meningkatkan kemampuan kepala sekolah dalam penyusunan RKJM dilakukan melalui langkah-langkah sebagai berikut: a) Perencanaan dilakukan dengan mempertimbangkan hasil identifikasi permasalahan; b) Kepala sekolah bersama-sama dengan kepala sekolah membahas jadwal pelaksanaan supervisi yang hendak dilakukan; c) Pengawas menyampaikan materi dalam kegiatan supervisi dalam bentuk office conference; d) Pada setiap akhir pertemuan pengawas meminta kepala sekolah untuk memperbaiki RKJM yang sudah disusun agar sesuai dengan format yang sudah terstandar; dan e) Pengawas memberikan pelatihan pada indikator yang masih menjadi kelemahan kepala sekolah; dan 2) Supervisi manajerial metode kelompok meningkatkan kemampuan kepala sekolah dalam penyusunan RKJM. Hal ini ditunjukkan dengan meningkatnya skor kemampuan kepala sekolah dalam penyusunan RKJM pada setiap siklus tindakan yang dilakukan.

Kata kunci: supervisi manajerial, metode kelompok, penyusunan RKJM

\section{PENDAHULUAN}

Rencana Kerja Jangka Menengah (RKJM) merupakan salah satu hal wajib yang dimiliki sekolah. Hal ini tertuang dalam Peraturan Pemerintah Nomor 19 Tahun 2005 tentang Standar Nasional Pendidikan, yaitu Pasal 53 ayat (1) yang menyatakan bahwa setiap satuan pendidikan dikelola atas dasar rencana kerja tahunan yang merupakan penjabaran rinci dari rencana kerja jangka menengah satuan pendidikan yang meliputi masa 4 (empat) tahun.

Tujuan utama penyusunan $\mathrm{RKS} / \mathrm{M}$ adalah agar sekolah/madrasah mengetahui secara rinci tindakan-tindakan yang harus dilakukan sehingga tujuan, kewajiban, dan sasaran pengembangan sekolah/madrasah dapat dicapai. RKS/M juga menjamin bahwa semua program dan kegiatan yang dilakukan untuk mengembangkan sekolah/madrasah sudah memperhitungkan harapan-harapan pemangku kepentingan dan kondisi nyata sekolah/ madrasah. Karena itu proses penyusunan RKS/M harus melibatkan semua pemangku kepentingan.

Pentingnya RKJM harus dimiliki sekolah ternyata tidak diiringi dengan kenyataan yang mengindikasikan bahwa RKJM di kebanyakan sekolah dasar disusun secara asal sekedar memenuhi kewajiban. Banyak kepala sekolah menganggap bahwa RKJM tidak terlalu penting bagi sekolah dasar. Sehingga tidak jarang ditemui sekolah yang belum mempunyai RKJM. Padahal dengan melihat RKJM, akan dapat dilihat sejauh mana visi yang dimiliki seorang kepala sekolah.

Adanya RKJMyang disusun secara komprehensifakan menunjukkan ketangguhan seorang kepala sekolah. Hal ini dikemukakan oleh Wheelen dan Hunger (1995) yang mengatakan bahwa ketangguhan utama kepala sekolah ada pada penguasaan ilmu dan keterampilan yang baik dalam merencanakan program sekolahnya sehingga dapat meraih keunggulan. Dalam mewujudkan cita-cita kepala sekolah hendaknya menempuh empat langkah 
stategis; yaitu pertama menganalisis konteks eksternal dan internal; kedua merumuskan visi, misi, tujuan dan strategi, ketiga menerapkan strategi dalam pelaksanaan program, dan keempat memonitor dan mengevaluasi program.

Keempat langkah strategis itu, ujungnya adalah mewujudkan keunggulan mutu siswa atau lulusan. Lulusan berkeunggulan adalah yang memiliki dan dapat menguasai materi pelajaran, terampil menerapkan ilmu yang diperolehnya, menguasai cara belajar sehingga penguasaannya dapat digunakan dalam memecahkan masalah kehidupannya.

Selain empat langkah strategis, terdapat empat langkah utama menjamin mutu yang wajib kepala sekolah tunaikan. Pertama merumuskan strategi atau metode dalam perencanaan (plan) berdasarkan pencapaian program sebelumnya. Dalam perencanaan kepala sekolah perlu memperhitungkan kekuatan sumber daya yang sekolah miliki sehingga target selalu disesuaikan dengan kemampuan nyata untuk mewujudkannya. Kedua, menerapkan strategi atau melaksanakan kegiatan sesuai dengan program. Ketiga, memonitor dan mengevaluasi proses dan hasil pekerjaan, melaksanakan perbaikan proses pekerjaan untuk memperbaiki pencapaian. Keempat, menggunakan hasil monitoring datan evaluasi sebagai dasar untuk melaksanakan perbaikan berkelanjutan. Siklus kegiatan itu sesuai dengan konsep yang dikembangkan oleh Sallis (2003) yang sangat terkenal dengan model plan, do, check, act.

Hal tersebut di atas ternyata belum begitu disadari oleh kebanyakan kepala sekolah, yang berdampak pada adanya anggapan bahwa penyusunan RKJM hanyalah sekedar menggugurkan kewajiban. Hal yang sama terjadi juga di Sekolah Dasar di Gugus VII Durma UPTD Dikpora Kecamatan Jebres Kota Surakarta.

Dari 5 (lima) sekolah yang ada, baru ada satu sekolah yang sudah mempunyai RKJM dengan susunan yang sudah agak lengkap. Bahkan saat diminta membuat analisis SWOT untuk mengetahui kekuatan dan kelemahan masing-masing sekolah, hampir semua kepala sekolah belum memahami secara optimal.

Salah satu usaha yang dapat dilakukan untuk meningkatkan kemampuan kepala sekolah dalam penyusunan RKJM adalah dengan memberikan pembinaan. Pembinaan kepada kepala sekolah tersebut dapat dilakukan oleh Pengawas Sekolah melalui kegiatan supervisi manajerial metode kelompok yang dilakukan. Adanya supervisi manajerial tersebut diharapkan dapat meningkatkan kemampuan kepala sekolah dalam penyusunan RKJM.

Berdasarkan perumusan masalah di atas selanjutnya dapat dirumuskan hipotesis dan tujuan penelitian. Adapun tujuan penelitian ini adalah sebagai berikut: 1) Untuk mendeskripsikan pelaksanaan supervisi manajerial metode kelompok untuk meningkatkan kemampuan kepala sekolah dalam penyusunan RKJM; dan 2) Untuk meningkatkan kemampuan kepala sekolah dalam penyusunan RKJM bagi Kepala Sekolah di Gugus VII Durma UPTD Dikpora Kecamatan Jebres Kota Surakarta melalui supervisi manajerial metode kelompok.

\section{METODE}

Sesuai dengan permasalahan yang diteliti, maka penelitian tindakan ini dilaksanakan di Gugus VII Durma UPTD Dikpora Kecamatan Jebres Kota Surakarta. Adapun waktu penelitian dilaksanakan pada semester genap tahun pelajaran 2011/2012.

Penelitian dilakukan selama 10 (sepuluh) minggu, yaitu dimulai pada minggu I bulan Pebruari tahun 2012 hingga minggu ke II bulan April 2012. Subjek dalam penelitian ini adalah 
kepala sekolah di Gugus VII Durma UPTD Dikpora Kecamatan Jebres Kota Surakarta, yang terdiri dari 5 orang kepala sekolah. Adapun objek penelitian berupa peningkatan kemampuan dalam penyusunan RKJM melalui supervisi manajerial metode kelompok.

Penelitian dilakukan dengan dua siklus tindakan. Setiap siklus diakhiri dengan tahapan refleksi. Data yang diperoleh dianalisis dan dimaknai dengan menggunakan analisis deskriptif prosentase dan untuk mengetahui perubahan hasil tindakan dilakukan dengan membandingkan hasil supervisi pada tindakan siklus sebelumnya.

Teknik pengambilan data dilakukan dengan cara observasi dan dokumen.Metode observasi digunakan untuk mengumpulkan data-data yang berkaitan dengan proses supervisi yang dilakukan. Metode dokumentasi digunakan untuk mempelajari dan menyeleksi dokumen yang relevan dengan penelitian.

Penilaian RKJM dilakukan dengan menggunakan instrumen yang disusun oleh peneliti. RKJM dinilai berdasarkan 3 (tiga) aspek yang terdiri dari 20 indikator. Skoring diberikan dengan rentang antara $1-5$ untuks setiap indikator. Dengan demikian maka skor terendah yang mungkin diperoleh adalah 20, dan skor tertinggi adalah 100.Skor akhir yang diperoleh selanjutnya diklasifikasikan ke dalam 4 (empat) kategori sebagai berikut:

Tabel 1

Kategori Penilaian RKJM

\begin{tabular}{cc}
\hline Rentang Skor & Kategori \\
\hline$<60$ & Kurang (K) \\
$60-<75$ & Cukup (C) \\
$75-<86$ & Baik (B) \\
$86-100$ & Amat Baik (AB) \\
\hline
\end{tabular}

Teknik analisis data dilakukan dengan mengikuti prosedur analisis model alur dari Kemmis dan Taggart. Teknik ini intinya adalah mengidentifikasi perkembangan dan perubahan subjek setelah subjek diberi perlakuan khusus atau dikondisikan pada situasi tertentu dengan tindakan dalam kurun waktu tertentu dan berulang-ulang sampai program dinyatakan berhasil.

Untuk mengukur keberhasilan tindakan, peneliti merumuskan indikator-indikator ketercapaian program supervisi manajerial metode kelompok untuk meningkatkan kemampuan kepala sekolah dalam penyusunan RKJM bagi kepala sekolah di Gugus VII Durma UPTD Dikpora Kecamatan Jebres Kota Surakarta.

Indikator keberhasilan tindakan penelitian ini dirumuskan sebagai berikut: a) Kepala sekolah dianggap sudah mampu menyusun RKJM dengan kategori baik apabila sudah memperoleh skor > 76; dan b) Supervisi dianggap berhasil apabila jumlah kepala sekolah dengan kemampuan menyusun RKJM dengan kategori baik $>80 \%$ dari jumlah kepala sekolah yang menjadi subjek penelitian.

\section{HASIL DAN PEMBAHASAN}

Data hasil pengukuran kemampuan kepala sekolah di Gugus VII Durma UPTD Dikpora Kecamatan Jebres Kota Surakarta dalam penyusunan RKJM pada kondisi awal adalah sebagai berikut: 
Tabel 2

Hasil Penilaian RKJM Kondisi Awal

\begin{tabular}{|c|c|c|c|c|c|c|c|c|c|}
\hline \multirow{3}{*}{ No. } & \multirow{3}{*}{$\begin{array}{l}\text { Inisial } \\
\text { Nama } \\
\text { Subjek }\end{array}$} & \multicolumn{6}{|c|}{ Aspek Penilaian } & \multirow{3}{*}{ Total } & \multirow{3}{*}{ Ket } \\
\hline & & \multicolumn{2}{|c|}{$\mathbf{A}$} & \multicolumn{2}{|c|}{ B } & \multicolumn{2}{|c|}{$\mathrm{C}$} & & \\
\hline & & Skor & $\%$ & Skor & $\%$ & Skor & $\%$ & & \\
\hline 1. & YUN & 18 & $60.00 \%$ & 8 & $53.33 \%$ & 26 & $47.27 \%$ & 52 & $\mathrm{~K}$ \\
\hline 2. & SLA & 21 & $70.00 \%$ & 9 & $60.00 \%$ & 36 & $65.45 \%$ & 66 & $\mathrm{C}$ \\
\hline 3. & $\mathrm{KHO}$ & 20 & $66.67 \%$ & 9 & $60.00 \%$ & 36 & $65.45 \%$ & 65 & $\mathrm{C}$ \\
\hline 4. & WAH & 22 & $73.33 \%$ & 9 & $60.00 \%$ & 36 & $65.45 \%$ & 67 & $\mathrm{C}$ \\
\hline \multirow[t]{3}{*}{5.} & PUR & 24 & $80.00 \%$ & 9 & $60.00 \%$ & 43 & $78.18 \%$ & 76 & $\mathrm{~B}$ \\
\hline & Jumlah & 105 & & 44 & & 177 & & 326 & \\
\hline & Rata-rata & 21.00 & $70.00 \%$ & 8.80 & $58.67 \%$ & 35.40 & $64.36 \%$ & 65.20 & $\mathrm{C}$ \\
\hline \multicolumn{2}{|c|}{ Skor Terendah } & \multicolumn{2}{|c|}{18} & \multicolumn{2}{|r|}{8} & \multicolumn{2}{|c|}{26} & \multicolumn{2}{|c|}{52} \\
\hline \multicolumn{2}{|c|}{ Skor Tertinggi } & \multicolumn{2}{|c|}{24} & \multicolumn{2}{|r|}{9} & \multicolumn{2}{|c|}{43} & \multicolumn{2}{|c|}{76} \\
\hline
\end{tabular}

Sumber: Hasil Penilaian Awal

Berdasarkan hasil penilaian terhadap dokumen RKJM yang disusun kepala sekolah pada kondisi awal, dapat diketahui rata-rata kemampuan kepala sekolah dalam penyusunan RKJM adalah dengan kategori Cukup Baik (C). Hal ini ditunjukkan dengan skor rata-rata yang diperoleh sebesar 62.5, dengan skor tertinggi sebesar 76 dan skor terendah sebesar 52.

Penilaian pada aspek Pendahuluan (Kolom A) menunjukkan bahwa rata-rata skor yang diperoleh kepala sekolah adalah 21.00 atau dengan ketercapaian 70\%. Skor terendah diperoleh sebesar 18 atau dengan ketercapaian $60.00 \%$, dan skor tertinggi sebesar 24 atau dengan ketercapaian $80.00 \%$.

Penilaian pada aspek Kondisi Umum (Kolom B) menunjukkan bahwa rata-rata skor yang diperoleh kepala sekolah adalah 8.8 atau dengan ketercapaian 58.67.\%. Skor terendah diperoleh sebesar 8 atau dengan ketercapaian 53.33\%, dan skor tertinggi sebesar 9 atau dengan ketercapaian $60.00 \%$. Penilaian pada aspek rencana strategis (Kolom C) menunjukkan bahwa rata-rata skor yang diperoleh kepala sekolah adalah 35.40 atau dengan ketercapaian $64.36 . \%$. Skor terendah diperoleh sebesar 26 atau dengan ketercapaian $47.17 \%$, dan skor tertinggi sebesar 43 atau dengan ketercapaian 78.28\%.

Penilaian secara keseluruhan pada ketiga aspek penyusunan RKJM menunjukkan bahwa rata-rata skor yang diperoleh kepala sekolah adalah 65.20 atau dengan ketercapaian $65.20 . \%$. Skor terendah diperoleh sebesar 52 atau dengan ketercapaian $52.00 \%$, dan skor tertinggi sebesar 76 atau dengan ketercapaian 76.00\%. Hasil-hasil tersebut mengindikasikan bahwa kepala sekolah dengan kemampuan penyusunan RKJM kategori Kurang Baik (K) sebanyak 1 orang (20.00\%), Cukup Baik (C) sebanyak 3 orang (60.00\%), dan kategori Baik (B) sebanyak 1 orang $(20.00 \%)$.

Berdasarkan analisis dokumen RKJM yang sudah disusun oleh kepala sekolah, diketahui bahwa kelemahan mendasar yang dihadapi kepala sekolah adalah pada aspek penyusunan rencana strategis. Kelemahan mendasar tersebut disebabkan karena kepala sekolah belum memahami analisis SWOT dan perumusan identifikasi fungsi-fungsi yang diperlukan setiap sasaran. 
Kegiatan supervisi manajerial dengan metode kelompok pada tindakan Siklus I dilaksanakan dalam empat tahap kegiatan. Tahapan kegiatan tersebut meliputi perencanaan, pelaksanaan, observasi, dan refleksi.

Perencanaan program supervisi manajerial metode kelompok pada tindakan Siklus I dilakukan dengan memperhatikan hasil identifikasi permasalahan pada kondisi awal. Aktivitas yang dilakukan pada tahap perencanaan antara lain meliputi sebagai berikut: 1) Pengawas melakukan konsolidasi dengan para kepala sekolah tentang akan dilaksanakannya supervisi manajerial dengan metode kelompok untuk meningkatkan kemampuan kepala sekolah dalam penyusunan RKJM; 2) Pengawas bersama-sama dengan kepala sekolah membahas waktu pelaksanaan supervisi dan tempat yang akan digunakan; 3) Pengawas mempersiapkan materi supervisi berupa penyusunan RKJM; dan 4) Pengawas mempersiapkan instrumen supervisi.

Pelaksanaan kegiatan supervisi manajerial metode kelompok pada tindakan Siklus I dilakukan pada hari Sabtu, 10 Maret 2012. Kegiatan supervisi dilaksanakan dalam bentuk office conference di ruang kepala sekolah SD Negeri Kandangsapi No. 140 Kecamatan Jebres Kota Surakarta.

Adapun kegiatan yang dilakukan pada tindakan Siklus I antara lain adalah sebagai berikut: 1) Pengawas menyampaikan materi tentang tahapan-tahapan dalam penyusunan RKJM; 2) Pengawas dengan kepala sekolah berdiskusi membahas tentang kelemahan-kelemahan yang ditemui pada kondisi awal, yaitu tentang cara melakukan analisis SWOT, cara perumusan identifikasi fungsi-fungsi yang diperlukan setiap sasaran, dan cara merumuskan alternatif langkah pemecahan persoalan dengan kondisi sekolah; dan 3) Pada akhir pertemuan, pengawas meminta para kepala sekolah untuk memperbaiki RKJM yang sudah disusun masing-masing sekolah untuk diperiksa pada pertemuan berikutnya ketika pengawas melakukan kunjungan ke sekolah masing-masing. Kepala sekolah diberi waktu 2 (dua) minggu untuk memperbaiki RKJM yang sudah disusun sebelumnya.

Hasil penilaian terhadap RKJM yang telah diperbaiki oleh kepala sekolah di Gugus VII Durma UPTD Dikpora Kecamatan Jebres Kota Surakarta dalam penyusunan RKJM pada tindakan Siklus I adalah sebagai berikut:

Tabel 3

Hasil Penilaian RKJM Tindakan Siklus I

\begin{tabular}{|c|c|c|c|c|c|c|c|c|c|}
\hline \multirow{3}{*}{ No. } & \multirow{3}{*}{$\begin{array}{l}\text { Inisial } \\
\text { Nama } \\
\text { Subjek }\end{array}$} & \multicolumn{6}{|c|}{ Aspek Penilaian } & \multirow{3}{*}{ Total } & \multirow{3}{*}{ Ket } \\
\hline & & \multicolumn{2}{|c|}{$\mathbf{A}$} & \multicolumn{2}{|c|}{ B } & \multicolumn{2}{|c|}{$\mathrm{C}$} & & \\
\hline & & Skor & $\%$ & Skor & $\%$ & Skor & $\%$ & & \\
\hline 1. & YUN & 21 & $70.00 \%$ & 9 & $60.00 \%$ & 32 & $58.18 \%$ & 62 & $\mathrm{C}$ \\
\hline 2. & SLA & 24 & $80.00 \%$ & 9 & $60.00 \%$ & 40 & $72.73 \%$ & 73 & $\mathrm{C}$ \\
\hline 3. & KHO & 24 & $80.00 \%$ & 12 & $80.00 \%$ & 40 & $72.73 \%$ & 76 & $\mathrm{~B}$ \\
\hline 4. & WAH & 24 & $80.00 \%$ & 12 & $80.00 \%$ & 43 & $78.18 \%$ & 79 & $\mathrm{~B}$ \\
\hline \multirow[t]{3}{*}{5.} & PUR & 27 & $90.00 \%$ & 12 & $80.00 \%$ & 46 & $83.64 \%$ & 85 & B \\
\hline & Jumlah & 120 & & 54 & & 201 & & 375 & \\
\hline & Rata-rata & 24.00 & $80.00 \%$ & 10.80 & 0.72 & 40.20 & $73.09 \%$ & 75.00 & $\mathrm{C}$ \\
\hline \multicolumn{2}{|c|}{ Skor Terendah } & \multicolumn{2}{|c|}{21} & \multicolumn{2}{|r|}{9} & \multicolumn{2}{|c|}{32} & \multicolumn{2}{|c|}{62} \\
\hline \multicolumn{2}{|c|}{ Skor Tertinggi } & \multicolumn{2}{|c|}{27} & \multicolumn{2}{|c|}{12} & \multicolumn{2}{|c|}{46} & \multicolumn{2}{|c|}{85} \\
\hline
\end{tabular}

Sumber: Hasil Penilaian Siklus I 
Berdasarkan hasil penilaian terhadap dokumen RKJM yang disusun kepala sekolah pada pada tindakan Siklus I, dapat diketahui rata-rata kemampuan kepala sekolah dalam penyusunan RKJM adalah dengan kategori Cukup Baik (C). Hal ini ditunjukkan dengan skor rata-rata yang diperoleh sebesar 75.0, dengan skor tertinggi sebesar 85 dan skor terendah sebesar 62.

Berdasarkan analisis dokumen RKJM yang sudah disusun oleh kepala sekolah, diketahui bahwa kelemahan yang masih dihadapi oleh kepala sekolah adalah pada aspek penyusunan rencana strategis. Kelemahan tersebut disebabkan karena kepala sekolah masih belum memahami analisis SWOT dan perumusan identifikasi fungsi-fungsi yang diperlukan setiap sasaran.

Berdasarkan hasil penilaian dokumen RKJM pada tindakan Siklus I, selanjutnya dapat diperoleh refleksi hasil tindakan sebagai berikut: 1) Supervisi manajerial metode kelompok dapat meningkatkan kemampuan kepala sekolah dalam penyusunan RKJM. Hal ini ditunjukkan dengan meningkatnya kemampuan kepala sekolah dalam penyusunan RKJM setiap aspek penilaian. Tingkat kemampuan kepala sekolah dalam penyusunan RKJM mengalami peningkatan, yaitu dari 65.20 atau dengan ketercapaian 65.20.\% pada kondisi awal, meningkat menjadi 75.00 atau dengan ketercapaian $75.00 \%$ pada tindakan Siklus I; 2) Peningkatan kemampuan kepala sekolah dalam penyusunan RKJM masih belum optimal. Hal ini ditunjukkan dengan skor rata-rata yang diperoleh masih di bawah skor dengan kategori baik, yaitu dengan skor $\geq 76$; dan 3) Kelemahan yang masih ada pada kepala sekolah dalam penyusunan RKJM adalah pada aspek penyusunan rencana strategis. Kelemahan tersebut disebabkan karena kepala sekolah masih belum memahami analisis SWOT dan perumusan identifikasi fungsi-fungsi yang diperlukan setiap sasaran. Untuk itu fokus perbaikan pada tindakan siklus II adalah pada aspek-aspek tersebut.

Perencanaan tindakan pada Siklus II didasarkan pada hasil refleksi tindakan Siklus I. Berdasarkan hasil refleksi dari tindakan siklus sebelumnya, maka tindakan pada Siklus II difokuskan pada aspek rencana strategis, khususnya pada indikator-indikator analisis SWOT dan perumusan identifikasi fungsi-fungsi yang diperlukan setiap sasaran.

Adapun aktivitas yang dilakukan pengawas pada tahap perencanaan adalah sebagai berikut: 1) Pengawas melakukan konsolidasi dengan para kepala sekolah tentang akan dilaksanakannya supervisi manajerial dengan metode kelompok tindakan Siklus II untuk meningkatkan kemampuan kepala sekolah dalam penyusunan RKJM; 2) Pengawas bersamasama dengan kepala sekolah membahas waktu pelaksanaan supervisi dan tempat yang akan digunakan; 3) Pengawas mempersiapkan materi supervisi berupa penyusunan RKJM pada aspek penyusunan rencana strategis; dan 4) Pengawas mempersiapkan instrumen supervisi.

Pelaksanaan kegiatan supervisi manajerial metode kelompok pada tindakan Siklus I dilakukan pada hari Sabtu, 14 April 2012. Kegiatan supervisi dilaksanakan dalam bentuk office conference di ruang kepala sekolah SD Negeri Kandangsapi No. 140 Kecamatan Jebres Kota Surakarta.

Adapun kegiatan yang dilakukan pada tindakan Siklus II adalah sebagai berikut: 1) Pengawas menyampaikan hasil analisis RKJM yang sudah disusun kepala sekolah pada tindakan Siklus I. Pengawas memberikan masukan kepada kepala sekolah tentang kelemahan-kelemahan yang masih ada pada RKJM yang disusun sebelumnya; 2) Pengawas 
Tabel 3. Komparasi Rerata Antar Sel pada Kolom yang Sama

\begin{tabular}{lccc}
\hline & Hasil & DK & Keputusan \\
\hline $\mathrm{F}_{11-21}$ & 1,943705 & 11,85488 & $\mathrm{H}_{0}$ tidak ditolak \\
\hline $\mathrm{F}_{12-22}$ & 0,0000701 & 11,85488 & $\mathrm{H}_{0}$ tidak ditolak \\
\hline $\mathrm{F}_{13-23}$ & 12,35281 & 11,85488 & $\mathrm{H}_{0}$ ditolak \\
\hline
\end{tabular}

Sumber: data diolah 2016

Hasil uji komparasi rerata antar strategi pembelajaran (SP) ditinjau dari KAMt menyatakan tidak ada SP yang mempunyai perbedaan rerata yang signifikan sehingga dapat berpengaruh terhadap hasil belajar matematika. Hal ini berarti karakteristik antara STAD dan TPS untuk KAMt sama dengan karaktersitik rerata marginal SP. Gambar 9 menyatakan rerata marginal STAD lebih tinggi dibanding rerata marginal TPS. Hal ini berarti strategi pembelajaran STAD lebih baik dari pada TPS. Dengan pemikiran yang sama, pada KAMs strategi pembelajaran STAD lebih baik dari pada TPS. Hal ini juga berlaku pada KAMr.

Hasil ini sesuai dengan hasil penelitian Tuna Gencosman dan Mustafa Dogru (2012) menyimpulkan educational based on STAD techniques has a higher effect on the selfefficacy perceptions, academic achievement and reducing test anxiety of students. Hal ini bermakna bahwa penggunaan strategi pembelajaran STAD kepada siswa dapat meningkatkan hasil belajar matematika. Oleh kerena itu, pada kemampuan awal matematika, hasil belajar matematika dengan menerapakan strategi pembelajaran STAD lebih baik dari pada hasil belajar matematika dengan menerapakan strategi pembelajaran TPS.

Tabel 4. Komparasi Rerata Antar Sel pada Baris yang Sama

\begin{tabular}{lccl}
\hline & Hasil & DK & \multicolumn{1}{c}{ Keputusan } \\
\hline $\mathrm{F}_{11-12}$ & 3,786439 & 11,85488 & $\mathrm{H}_{0}$ tidak ditolak \\
$\mathrm{F}_{11-13}$ & 6,731447 & 11,85488 & $\mathrm{H}_{0}$ tidak ditolak \\
$\mathrm{F}_{12-13}$ & 0,441751 & 11,85488 & $\mathrm{H}_{0}$ tidak ditolak \\
$\mathrm{F}_{21-22}$ & 0,308846 & 11,85488 & $\mathrm{H}_{0}$ tidak ditolak \\
$\mathrm{F}_{21-23}$ & 20,68802 & 11,85488 & $\mathrm{H}_{0}$ ditolak \\
$\mathrm{F}_{22-23}$ & 18,94753 & 11,85488 & $\mathrm{H}_{0}$ ditolak \\
\hline
\end{tabular}

Sumber: data diolah 2016

Hasil uji komparasi rerata antara KAMt dan KAMs dengan menggunakan STAD memutuskan bahwa rerata yang diperoleh dari KAMt tidak berbeda jauh dengan rerata yang diperoleh KAMs. Hal ini berarti karakteristik antara KAMt dan KAMs sama dengan karakteristik rerata marginal KAM. Gambar 9 menyatakan rerata marginal KAMt lebih tinggi dibanding rerata marginal KAMs. Hal ini berarti KAMt lebih baik dari pada KAMs dengan menerapkan STAD. Dengan pemikiran yang sama KAMt lebih baik dari pada KAMr dan KAMs lebih baik dari pada KAMr.

Hasil ini sesuai dengan penelitian yang dilakukan Irawati (2014) yang menyimpulkan bahwa siswa berkemampuan awal tinggi memperoleh hasil belajar pemahaman dan hasil 
belajar tingkat tinggi yang lebih baik dibandingkan dengan siswa berkemampuan awal rendah. Hal ini bermakna bahwa siswa yang memiliki KAMt mendapatkan hasil belajar matematika yang lebih baik dibandingkan siswa dengan KAMs dan KAMr. Penerapan strategi pembelajaran STAD pada siswa dengan KAMt memiliki hasil belajar yang lebih baik dari siswa dengan KAMs dan KAMr pada kelas yang sama.

Hasil uji komparasi rerata antara KAMt dan KAMs dengan menggunakan TPS memutuskan bahwa rerata yang diperoleh dari KAMt tidak berbeda jauh dengan rerata yang diperoleh KAMs. Hal ini berarti karakteristik antara KAMt dan KAMs sama dengan karakteristik rerata marginal KAM. Gambar 9 menyatakan rerata marginal KAMt lebih tinggi dibanding rerata marginal KAMs. Hal ini berarti KAMt lebih baik dari pada KAMs dengan menggunakan TPS. Dengan pemikiran yang sama KAMt lebih baik dari pada KAMr dan KAMs lebih baik dari pada KAMr.

Hasil ini sesuai dengan penelitian yang dilakukan Anggraini dkk (2013) yang menyimpulkan bahwa ada hasil belajar yang signifikan antara kelompok siswa yang berkemampuan awal tinggi dan rendah. Hal ini bermakna bahwa kemampuan awal matematika yang dimiliki siswa memberikan pengaruh terhadap hasil belajar matematika. Oleh karena itu, pada strategi pembelajaran TPS, KAMt lebih baik dibanding KAMs dan KAMr terhadap hasil belajar matematika.

Penggunaan strategi pembelajaran STAD dan TPS pada siswa dengan KAMt berdampak pada hasil belajar matematika yang lebih baik dibanding siswa dengan KAMs dan KAMr. Oleh karena itu disimpulkan bahwa interaksi strategi pembelajaran dan kemampuan awal matematika berpengaruh terhadap hasil belajar matematika.

Faktor yang paling berpengaruh terhadap hasil belajar ialah kemampuan awal matematika yang dimiliki oleh siswa. Berdasarkan Tabel 1 selisih hasil perhitungan antara $\mathrm{F}_{\text {obs }}$ dan $\mathrm{F}_{\alpha}$ pada kemampuan awal matematika lebih besar dari pada selisih perhitungan variabel lainnya. Hal ini memperkuat bahwa dukungan kemampuan awal matematika yaitu kemampuan yang telah dimiliki siswa sebelum ia mengikuti pelajaran yang diberikan yang berfungsi sebagai pengungkapan kembali pengetahuan baru siswa serta keistimewaan STAD dan TPS sebagai pembelajaran kooperatif yang menekankan pada interaksi siswa dalam kelompok berdampak pada hasil belajar matematika yang lebih baik. Oleh karena itu, hasil belajar matematika yang diperoleh siswa selain dipengaruhi oleh strategi pembelajaran STAD dan strategi pembelajaran TPS serta kemampuan awal matematika juga dipengaruhi oleh interaksi di antara keduanya.

\section{SIMPULAN}

Strategi pembelajaran STAD dimulai dengan menyampaikan tujuan pembelajaran, mengkomunikasikan kompetensi dasar yang akan dicapai serta memotivasi tentang materi yang akan diajarkan siswa. Selanjutnya guru menyajikan sedikit materi yang akan dipelajari dan membentuk kelompok heterogen beranggotakan 4 siswa berdasarkan kemampuan awal matematika. Siswa saling bekerja sama dan berinteraksi memberikan tanggapan terhadap materi maupun tugas yang diberikan guru. Kemudian kelompok mengemukakan hasil diskusi di depan kelas agar terjadi pertukaran pendapat yang lebih luas dan interaksi antar kelas. Selanjutnya guru memberikan kuis untuk mengetahui apakah siswa telah menguasai materi yang sedang dipelajari yaitu tentang Turunan Fungsi dan dikerjakan secara individu. Skor 
mampuan siswa, tetapi pada siklus II guru telah memvariasikan metode mengajarnya sehingga PBM lebih menyenangkan. Dari 11 orang yang bermasalah pada siklius I, tinggal 2 orang pada siklus II.

c. Mengorganisasikan siswa dalam belajar. Pada siklus I sebahagian besar guru mengajar secara klasikal, tetapi pada siklus II seiring dengan variasi metode mengajar yang digunakan guru, siswa dikelompokan dalam kelompok kelompok kecil sehingga siswa terlihat bebas bertanya pada teman sejawat. Dari 10 orang yang bermasalah pada siklus I, tinggal 1 orang pada siklus II.

d. Guru tidak melaksanakan penilaian selama proses berlansung. Pada siklus I guru fokus memperhatikan siswa yang pandai kesulitan belajar yang dialami sebahagian besar siswa tidak diketahui karena guru tidak berkeliling memberikan bantuan kepada siswa yang mengalami kesulitan. Pada siklus II guru berkeliling memberikan bantuan seperlunya sehingga kesulitan belajar yang dialami siswa dapat diatasi. Pada siklus I ada 10 orang guru yang bermasalah, dan pada siklus II tinggal 1 orang.

Berdasarkan data tersebut dan pengamatan, peneliti menyimpulkan bahwa pembelajaran yang dilakukan oleh guru telah sesuai dengan ketentuan yang digariskan pemerintah yaitu sesuai dengan Undang-Undang Republik Indonesia No. 20 Tahun 2003 tentang sistem Pendidikan Nasional pasal 39 ayat 2 yang menyebutkanPendidik merupakan tenaga profesional yang bertugas merencanakan danmelaksanakan proses pembelajaran, menilai hasil pembelajaran, melakukanpembimbingan dan pelatihan, serta melakukan penelitian dan pengabdian kepadamasyarakat, terutama bagi pendidik pada perguruan tinggi.Disisi lain peneliti dapat menyimpulkan bahwa pelaksanaan supervisi telah berhasil yaitu meningkatnya kemampuan guru dalam membuat perencanaan dan pelaksanaan pengajaranserta sesuai dengan apa yangdikemukakan oleh Oteng Sutisna (1989:265-266) bahwa peran supervisi merupakan bantuan profesional dan teknis kepada guru dengan maksud untuk meningkatkan kemampuan guru dan melalui itu meningkatkan kualitas pendidikan.

\section{SIMPULAN}

Kesimpulan dari hasil penelitian dan pembahasan adalah sebagai berikut:

1. Pemberian bimbingan di awal penyusunan Silabus, RPP, dan pelaksanaan Pembelajaran dapat mengoptimalkan hasil supervisi yaitumeningkatkan Propesionalisme guru. Hal ini dapat dilihat dari peningkatan kemampuan guru dari keadaan awal, siklus I, dan siklus II berdasarkan data yang diperoleh peneliti.

2. Supervisi Akademik dapat meningkatkan kemampuan guru untuk menjadi guru yang profesional. Dari 13 guru yang menjadi mitra peneliti kemampuan profesionalnya terlihat meningkat secara berarti. Dalam menyusun RPP pada siklus I dari 13 guru, seluruhnya (100\%) memperoleh nilai dibawah 90. Namun pada siklus II nilai semua guru meningkat sehingga tinggal 1 orang guru yang nilainya dibawah 90 (7,69\%). Demikian juga pada kemampuan pelaksanaan pembelajaran, pada siklus I hanya 2 orang guru yang nilainya 
di atas 80 (15\%). Namun pada sikuls II nilai guru meningkat secara keseluruhan, tinggal 1 orang guru yang nilainya dibawah 90 .

\section{DAFTAR PUSTAKA}

Adam \& Dickey, Basic Principles of Supervision, New York: American Book Company, 1959.

Arikunto, Suharsimi, Manajemen Pengajaran Secara Manusiawi, Jakarta: Rineka Cipta,1993. Azwar, Azrul, Pengantar Administrasi, Jakarta: P.T. Bumi Aksara, 1988.

Daryanto, H.M., Administrasi Pendidikan , Jakarta: Rineka Cipta, 1998.

Engkoswara, Dasar-dasar Manajemen Pendidikan, Jakarta Dirjen Dikti Depdikbud,1998.

Halsey, George D., Bagaimana Memimpin dan Mengawasai Pegawai Anda, Jakarta: Rineka Cipta,1994.

Nawawi, Hadari, Administrasi Pendidikan, Jakarta: Gunung Agung, 1984.

Pidarta, Made, Manajemen Pendidikan Indonesia Jakarta; Bina Aksara, 1998.

Purwanto, Ngalim, Administrasi dan Supervisi Pendidikan, Bandung:2005.

Pusdiklat Pegawai Depdiknas, Manajamen Sekolah, Depok: Depdiknas, 2007.

Suhertian, Piet, Konsep Dasar \& Teknik Supervisi Pendidikan, Jakarta: Rineka Cipta, 2000.

Sutisna, Oteng, Administrasi Pendidikan, Dasar Teoritis Untuk Praktek Profesional (Bandung: Angkasa, 1985 